\title{
ANALISIS PENGARUH PELAYANAN PUSKESMAS DAN KINERJA PEGAWAI TERHADAP KEPUASAN PELANGGAN DI PUSKESMAS DINOYO KOTA MALANG JAWA TIMUR
}

\author{
Rully Suwartiningsih \\ Mahasiswa Magister Manajemen Pascasarjana Universitas Islam Malang \\ Email : liongkristijanto@gmail.com
}

\begin{abstract}
Abstrak
Masalah pelayanan sebenarnya bukanlah hal yang sulit atau rumit, tetapi apabila hal ini kurang diatasi maka dapat menimbulkan masalah serta peningkatan kinerja pegawai yang bagus merupakan kunci sukses untuk membangun keberhasilan Puskesmas dalam melayani pasien. Untuk meningkatkan kualitas pelayanan dan kinerja pegawai, Puskesmas Dinoyo Kota Malang akan mampu mendapatkan profitabilitas yang diperoleh dari kepuasan pasien oleh sebab diharapkan mampu meningkatkan kualitasnya puskesmas. Tujuan dari penelitian ini adalah: untuk menganalisis pengaruh pelayanan Puskesmas dan kinerja pegawai terhadap kepuasan pelanggan di Puskesmas Dinoyo Kota Malang Jawa Timur. Sampel yang digunakan dalam penelitian ini adalah pasien atau pelanggan dari Puskesmas Dinoyo selama satu minggu pada bulan Nopember tahun 2017. Hasil penelitian menunjukkan bahwa pengaruh pengaruh Puskesmas dan kinerja pegawai terhadap kepuasan pelanggan di Puskesmas Dinoyo Kota Malang Jawa Timur negatif dan tidak signifikan. Dalam penelitian ini juga mengindikasikan bahwa secara simultan pelayanan Puskesmas dan kinerja pegawai memiliki pengaruh terhadap kepuasan pelanggan Puskesmas.
\end{abstract}

Kata kunci : pelayanan puskesmas, kinerja pegawai, kepuasan pelanggan

\begin{abstract}
The problem of service is not difficult and complicated, but if this matter is not be overcame so it can make some problems and a good employee performance is a key of success to build the success of Community Health Center on servicing the patient. To develop the quality of service and employee performance, Community Health Center Dinoyo Malang City will be able to get the profitability that obtained from the satisfaction customer, so for that reason it expected to develop the quality of Community Health Center. The objectives of this research is: to analyze the effect of the service of Community Health Center and the Employee Performance to Customer Satisfaction in Community Health Center Dinoyo Malang City East Java. Using of sample from this study is the patient of Community Health Center Dinoyo for a week on November at 2017. The result of this research shows that the service of Community Health Service and Employee Performance to Customer Satisfaction in Community Health Center in Dinoyo Malang City East Java is negative and not significant. In this research also indicates that the service of Community Health Center and Employee Performance have the effect to the satisfaction customer of Community Health Center simultaneously.
\end{abstract}

Keyword : service of community health center, employee performance, satisfaction performance 


\section{PENDAHULUAN}

Pelayanan puskesmas yang bermutu merupakan kunci sukses dan dasar untuk membangun keberhasilan dan kepercayaan pelanggan. Sikap dan keahlian akan menentukan bentuk pelayanan puskesmas yang bermutu. Produk apapun yang dihasilkan oleh pelayanan puskesmas tidak terlepas dari unsur kualitas layanan, jasa sebagai produk layanan upaya kuratif, upaya prefentif dan promotif maupun upaya kesehatan penunjang. Oleh karena itu perhatian terhadap kepuasan pelanggan menjadi prioritas yang harus ditingkatkan sehingga Puskesmas Dinoyo Kota Malang mampu memberikan kepuasan terhadap pelanggannya. Masalah pelayanan sebenarnya bukanlah hal yang sulit atau rumit, tetapi apabila hal ini kurang diperhatikan maka dapat menimbulkan hal-hal yang rawan karena sifatnya yang sangat sensitive. Sistem pelayanan perlu didukung oleh kualitas layanan, fasilitas yang memadai etika atau tata karma. Sedangkan tujuan memberikan pelayanan adalah untuk memberikan kepuasan pelanggan, sehingga berakibat dengan dihasilkannya nilai tambah atau citra positif bagi Puskesmas Dinoyo Kota Malang.

Sedangkan penilaian kinerja pegawai juga tidak kalah pentingnya, penilaian kinerja pegawai adalah proses penilaian hasil kerja yang akan digunakan oleh pihak manajemen untuk untuk memberikan informasi kepada para pegawai secara individual, tentang mutu hasil pekerjaannya dipandang dari sudut pandang kepentingan Puskesmas. Penilaian yang dilakukan secara teratur bertujuan meindungi Puskesmas dalam mencapai tujuannya peniliaian kinerja pegawai yang dilakukan secara obyektif, tepat, dan didokumentasikan secara baik cenderung menurunkan potensi penyimpangan yang dilakukan pegawai sehingga kinerjanya diharapkan harus bertambah baik sesuai dengan kinerja yang dibutuhkan pegawainnya. Pada dasarnya dari penyelenggaraan pelayanan kesehatan di Puskesmas Dinoyo Kota Malang adalah memenuhi kebutuhan dan tuntutan dari pelanggan kesehatan (pasien) dimana pasien mengharapkan suatu penyelesaian dari masalah kesehatanya di Puskemas Dinoyo Kota Malang, oleh karena itu pasien memandang bahwa Puskesmas Dinoyo mampu dalam hal pemberian pelayanan medis dalam upaya penyembuhan yang berkualitas, cepat tanggap atas keluhan serta penyediaan pelayanan kesehatan tingkat pertama yang nyaman dan berkualitas.

\section{KAJIAN TEORI}

Tingkat kepuasan pelanggan dapat menunjukkan karakteristik atau atibut apa dari produk atau jasa yang membuat pelanggan tidak puas, tujuan dari pengukuran tingkat kepuasan pelanggan adalah untuk dapat segera mengetahui faktor - faktor yang membuat para pelanggan tidak puas untuk segera diperbaiki, sehingga pelanggan tidak kecewa. Dalam 
memberikan pelayanan, setidaknya Puskesmas Dinoyo harus memenuhi lima kriteria pelayanan yang sering disebut RATER, sehingga dapat menciptakan pasien atau pelanggan yang loyal, yaitu realibility (kehandalan) assurance (jaminan) tangible (bukti fisik), empathy (komunikasi) dan responsiveness (cepat tanggap). (Tjiptono, 2006). Kepuasan pelanggan adalah tingkat perasaan seseorang setelah membandingkan kinerja atau hasil yang dirasakan kemudian dibandingkan dengan harapan, tingkat kepuasan pelanggan sangat tergantung pada mutu suatu produk atau jasa (Suprapto, 2011). Apabila pelanggan tidak puas terhadap suatu pelayanan yang disediakan, maka pelayanan tersebut dapat dipastikan tidak efektif dan efisien. Dalam hal ini terutama pelayanan publik. Sehingga dapat diambil kesimpulan bahwa kepuasan pelanggan merupakan suatu persepsi pelanggan bahwa harapannya telah terpenuhi atau terlampaui. Sehingga kepuasan pelanggan dapat tercapai apabila sebuah produk atau jasa memenuhi atau melampaui harapan pelanggan, biasanya pelanggan akan merasa puas

Berdasarkan latar belakang permasalahan tersebut maka peneliti dalam hal ini melakukan penelitian berjudul "Analisis Pengaruh Pelayanan Puskesmas dan Kinerja Pegawai Terhadap Kepuasan Pelanggan Di Puskesmas Dinoyo Kota Malang Jawa Timur".

\section{METODE PENELITIAN}

Metode yang digunakan dalam penelitian ini adalah metode deskriptif. Metode deskriptif bertujuan untuk memberi gambaran tentang suatu masyarakat atau suatu kelompok orang tertentu atau gambaran tentang suatu gejala atau hubungan antara dua gejala atau lebih.

Populasi yang dijadikan target penelitian adalah semua pasien atau pelanggan yang datang dan berobat di Puskesmas Dinoyo. Sedangkan sampelnya diambil sebanyak 100 orang yang diambil secara independen pada tiap hari selama satu minggu. rata-rata jumlah pasien atau pengunjung di puskesmas Dinoyo adalah 120-200 pasien per hari. Variabel independen daam peneitian ini adalah pelayanan puskesmas dan kinerja pegawai sedangkan variabel dependennya adalah kepuasan pelanggan di puskesmas dinoyo kota malang. Kedua variabel tersebut berkedudukan secara mandiri, tidak berkaitan, dan tidak saling mempengaruhi atau dipengaruhi satu sama lain. Instrumen ini tidak menggunakan uji terpakai, jadi instrumen penelitian tidak di uji coba.

\section{HASIL ANALISIS DATA Uji Normalitas}

Model regresi dapat dikatakan memenuhi asumsi normalitas jika residual yang diperoleh dari model regresi berdistribusi normal. Hipotesis yang digunakan dalam pengujian adalah:

$\mathrm{H}_{0}$ : Sebaran residual berdistribusi normal $\mathrm{H}_{1}$ : Sebaran residual tidak berdistribusi normal 
Tabel 5.1. Uji one sample Kolmogorov-Smirnov

\begin{tabular}{|l|l|}
\hline Residual & Signifikansi \\
\hline Model 1 & 0.296 \\
\hline
\end{tabular}

Berdasarkan histogram pada gambar 1 menunjukkan bahwa diagram batang mengikuti kurva normal yang terbentuk dan dari grafik P-P plot pada gambar 2 didapatkan bahwa data observasi berada disekitar garis diagonal, dan dari tabel 1 diatas, didapatkan nilai signifikansi dari pengujian one sample Kolmogorov-Smirnov sebesar 0.296 lebih besar dari a (0.05). Berdasarkan ketiga pengujian tersebut, diambil keputusan terima $\mathrm{H}_{0}$ yang artinya sebaran residual berdistribusi normal (asumsi tepenuhi)

\section{Uji Multikolinieritas}

Apabila nilai VIF > 10 maka menunjukkan adanya multikolinieritas. Dan apabila sebaliknya VIF $<10$ maka tidak terjadi multikolinieritas.

Tabel 5.2. Uji multikolinieritas dengan VIF

\begin{tabular}{|l|l|l|}
\hline Variabel & Tolerance & VIF \\
\hline X1 (kualitas pelayanan) & 0.889 & 1.125 \\
\hline X2 (Kinerja pegawai) & 0.889 & 1.125 \\
\hline
\end{tabular}

Berdasarkan tabel 2 di atas didapatkan bahwa semua nilai VIF dari masing-masing variabel bebas kurang dari 10 dengan nilai tolerance lebih dari 0.1 , yang artinya antar variabel bebas tidak terdapat korelasi yang cukup kuat atau tidak terdapat multikolinieritas (asumsi terpenuhi).

\section{Uji Heterokedastisitas}

Jika titik-titik yang ada membentuk pola tertentu yang teratur (bergelombang, melebar kemudian menyempit), maka mengindikasikan telah terjadi heteroskedastisitas (asumsi tidak terpenuhi). Sedangkan, jika tidak ada pola yang jelas, atau titik-titik menyebar di atas dan di bawah angka 0 pada sumbu $\mathrm{Y}$, maka tidak terjadi heteroskedastisitas (asumsi terpenuhi)/

Gambar 5.3. Uji Heterokedastisitas dengan Scatterplot

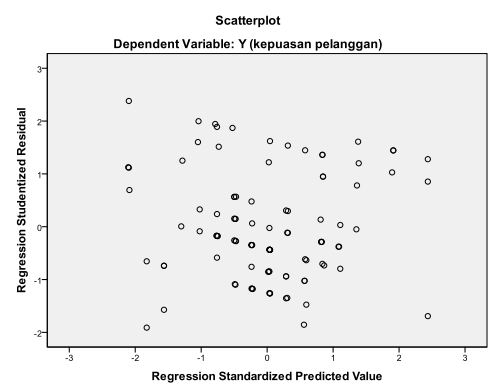

Dari hasil scatterplot pada gambar 3 diatas, terlihat titik-titik tersebar secara acak (tak berpola) baik di atas maupun di bawah angka 0 pada sumbu $Y$, dan dari hasil pengujian dengan uji rank spearman pada tabel 3 , 
didapatkan bahwa nilai signifikansi hubungan masing-masing variabel dengan absolute residualnya lebih besar dari a (0.05), yang artinya bahwa asumsi heteroskedastisitas terpenuhi (ragam residual homogen).

\section{PEMBAHASAN}

Besarnya kontribusi dari variabel independen secara simultan terhadap variabel dependen, berdasarkan hasil perhitungan pada tabel 3 dengan nilai koefisien determinasi ( $R$ Square) sebesar 0.099. Hasil tersebut menjelaskan sumbangan atau kontribusi dari variabel-variabel bebas (kualitas pelayanan (X1), dan kinerja pegawai(X2)) yang disertakan dalam persamaan regresi terhadap variabel $Y$ (kepuasan pelanggan) adalah sebesar 9.9\%, sedangkan 90.1\% lainnya disumbangkan oleh variabel bebas lainnya yang tidak dimasukkan ke dalam persamaan ini.

Terdapat pengaruh negatif dan tidak signifikan antara kualitas pelayanan terhadap kepuasan pelanggan pada Puskesmas Dinoyo Kota Malang. Hal ini dibuktikan dengan $r$ hitung sebesar 0,099 lebih besar dari $r$ tabel pada taraf signifikansi $5 \%$ dengan $\mathrm{N}=100$ sebesar 0,050 .

Terdapat hubungan negatif dan tidak signifikan antara kinerja pegawai terhadap kepuasan pelanggan pada Puskesmas Dinoyo Kota Malang. Hal ini dibuktikan dengan $r$ hitung sebesar 0,099 lebih besar dari $r$ tabel pada taraf signifikansi $5 \%$ dengan $\mathrm{N}=100$ sebesar 0,361 . 3 . Terdapat hubungan positif dan signifikan antara kualitas pelayanan dan kinerja Pegawai terhadap kepuasan pelanggan pada Puskesmas Dinoyo Kota Malang. Hal ini dibuktikan dengan $R$ hitung sebesar 0,861 dan hasil dari $F$ hitung adalah 5.352 lebih besar dari $F$ tabel pada taraf kesalahan $5 \%$ dan didasarkan pada pembilang $(k)=2$ dan penyebut $(n-k-1)=27$ yaitu sebesar 3.090.

Terdapat hubungan negatif dan tidak signifikan terhadap kepuasan pelanggan. Hal ini dibuktikan dengan $\mathrm{R}=$ Hitung sebesar 0,861 dan hasil dari f hitung 5.352 lebih besar dari f tabel dengan taraf kesalahan $5 \%$ dan didasarkan pada pembilang $(k)=2$ dan penyebutnya $(n-k-1)=27$ yaitu sebesar 3.090

\section{SIMPULAN DAN SARAN}

Berdasarkan hasil pembahasan di atas, mengenai analisis pengaruh pelayanan puskesmas dan kinerja pegawai terhadap kepuasan pelanggan di Puskesmas Dinoyo Kota Malang Jawa Timur terhadap kepuasan pelanggan pada Puskesmas Dinoyo Kota Malang, maka peneliti memberikan sumbangan ide atau pemikiran sehingga nantinya dapat meningkatkan kemajuan instansi sebagai berikut:

1. Pegawai hendaknya tepat waktu dan cepat dalam melayani pelanggan

2. Pegawai hendaknya membantu tanpa diminta pelanggan, proaktif memberikan informasi dan berusaha memberikan lebih dari apa yang dibutuhkan oleh pelanggan

3. Pegawai seharusnya memberikan pelayanan yang sudah ditetapkan sesuai jadwal pelayanan, selalu tepat waktu dan cepat dalam melayani pelanggan. 
4. Pegawai seharusnya lebih lebih mengutamakan apa yang diinginkan pelanggan.

5. Kualitas pelayanan kepada para pasien hendaknya lebih ditingkatkan agar pasien tidak menunggu terlalu lama dalam pengobatan.

\section{DAFTAR PUSTAKA}

Ainaini (2006). "Studi Terhadap Kepuasan atas Pelayanan Puskesmas di Surakarta"

Andriani (2017). Hubungan Mutu Pelayanan Kesehatan Dengan Kepuasan Pasien Diruangan Poli Umum Puskesmas Bukit Tinggi.

Arikunto, S. Prosedur Penelitian Suatu Pendekatan Praktik. Penerbit Bina Rupa Aksara. Jakarta 1989

Azwar, A. 1994 .Program menjaga mutu. Pelayanan kesehatan. Yayasan penerbit IDI, Jakarta

Boedijowono, N. 2007. Pengantar Statistika Ekonomi dan Bisnis. Yogyakarta: STIE YKPN

Budiarto (2015). "Kualitas Pelayanan Kesehatan di Puskesmas Kecamatan Enrekang Kabupaten Envekang"

Djati, S. P. 2005: Pengaruh Kinerja Pegawai Terhadap Kepuasan, Kepercayaan, dan Kesetiaan Pelanggan. (Jurnal Online, diakses 29 Maret 2013)

Gomes.2003. "Kriteria Penilaian Kinerja" Hal.97

Gusti Putu Ratih Kusuma Dewi, 2014. "Pengaruh Kualitas Pelayanan Terhadap Kepuasan dan Loyalitas Nasabah PT. BPR HOKI di Kabupaten Tabanan"

Hardiansyah. 2011, Kualitas Pelayanan Publik, Yogyakarta: Gava Media.

Juwandi, H. I. 2004. Kepuasan Pelayanan Jasa. Jakarta: Erlangga

Kotler, Philip. 2003. Manajemen Pemasaran. Jakarta. Gramedia

Kotlev (2005:342). Manajemen pemasaran, Jakarta Gramedia.

Noegroho 2005. "Proses Analisi Regresi Ganda dan Korelasi Ganda"

Philip, K. (2005:153). Manajemen Pemasaran, Jakarta Gramedia

Prawirisentono, P. 1999. Kebijakan Kinerja Pegawai). Yogyakarta : BPFE.

Randal Randa S. Schulev, Susan E, Jacson 2012. " Kesalahan-kesalahan Dalam Penilaian Kinerja", Hal. 100 - 104.

Retnowati (2008) "Kualitas Pelayanan Kesehatan di Puskesmas Bringin Kabupaten Semarang"

Rivai \& Basri .2012. "Input Proses dan Output “,Hal. 64

Sugiyono. 2002. Statistik untuk penelitian. Alfabeta, Bandung

Sulaiman, ES (2009) Aktivasi Tingkat Puskesmas

Tjiptono, F. 1996. Manajemen Jasa. Penerbit Andi. Yogyakarta

Zithaml, B. \& Pasuraman. 2008. A Multiple Item Scale For Measuring Consumer Perception of Service Quality. Journal of Retailing

Zulkarnain et al (2016). Nominal Fokus Group Discussion Dalam Penelitian di Lingkup Program Studi Dokter Layanan Primer 